\title{
APPLYING FUZZY ANALYTIC HIERARCHY PROCESS IN LOCATION MODE OF INTERNATIONAL LOGISTICS ON AIRPORTS COMPETITION EVALUATION
}

Shu-Chen Lin

Professor, Department of Marine Engineering, National Taiwan Ocean University., shuchen@ocit.edu.tw

Te-Yan Liang

Professor, Department of Shipping and Transportation Management, National Taiwan Ocean University, Keelung, Taiwan 20224, R.O.C.

Kuo-Liang Lee

Assistant Professor, Department of Marketing and Distribution Management, Overseas Chinese Institute of Technology, Taichung, Taiwan, R.O.C.

Follow this and additional works at: https://jmstt.ntou.edu.tw/journal

Part of the Business Commons

\section{Recommended Citation}

Lin, Shu-Chen; Liang, Te-Yan; and Lee, Kuo-Liang (2006) "APPLYING FUZZY ANALYTIC HIERARCHY PROCESS IN LOCATION MODE OF INTERNATIONAL LOGISTICS ON AIRPORTS COMPETITION EVALUATION," Journal of Marine Science and Technology. Vol. 14: Iss. 1, Article 3.

DOI: 10.51400/2709-6998.2076

Available at: https://jmstt.ntou.edu.tw/journal/vol14/iss1/3

This Research Article is brought to you for free and open access by Journal of Marine Science and Technology. It has been accepted for inclusion in Journal of Marine Science and Technology by an authorized editor of Journal of Marine Science and Technology. 


\title{
APPLYING FUZZY ANALYTIC HIERARCHY PROCESS IN LOCATION MODE OF INTERNATIONAL LOGISTICS ON AIRPORTS COMPETITION EVALUATION
}

\author{
Shu-Chen Lin*, Gin-Shuh Liang**, and Kuo-Liang Lee***
}

Key words: competitiveness criteria, value-added location mode, fuzzy analytic hierarchy process (FAHP).

\section{ABSTRACT}

This paper has three, main objectives: (a) the establishment of competitiveness criteria for the location mode of the airport; (b) this study first divides international logistics into two stages and four modes of development categories from the viewpoint of value-added. Then, the evaluation criteria for transshipment mode and re-processing export mode are established; (c) and integrates Fuzzy Analytic Hierarchy Process (FAHP) approach to the international competition level for a comparative analysis of the suitable location mode of each airport (Chiang Kai Shek, Hong Kong, and Singapore's Changi International Airport). The empirical results indicate that the proposed method can be used to identify the suitable location mode when international logistics system developed by airports.

\section{INTRODUCTION}

Due to the increasing of globalization and deregulation of the corporate world, many companies consider the entire world as a single marketplace. Furthermore, companies set up their production bases in many locations, purchase necessary raw materials from many for international logistics. In order to develop a high value-added distributing service and accumulate sufficient commodities, many owners of international factory operations have set up a handful of strategic bases of operation to stockpile their cargo. Furthermore,

Paper Submitted 04/15/05, Accepted 07/12/05. Author for Correspondence: Shu-Chen Lin. E-mail: shuchen@ocit.edu.tw.

*Assistant Proffessor, Department of Marketing and Distribution Management, Overseas Chinese Institute of Technology, Taichung, Taiwan, R.O.C.

**Professor, Department of Shipping and Transportation Management, National Taiwan Ocean University, Keelung, Taiwan 20224, R.O.C.

***Assistant Professor, Department of Marketing and Distribution Management, Overseas Chinese Institute of Technology, Taichung, Taiwan, R.O.C. many nations have set up logistics centers, foreign trade zones, and export processing zones in different countries, and market their finished products worldwide. Certain factors such as the globalization of corporate purchasing, the division of labor and production, and the marketing involved in the process of the global exchange of cargo have created an urgent need harbor districts and their surrounding areas. This has been done in an effort to strengthen national economic activity and to increase the profitability of harbor and airport districts. The location-to-location factors must be considered in developing different stages and modes of logistics activities. Moreover, individual locations have different modes of international logistics that are suitable for the development of a competitive edge. From the perspective of public organizations, it is vital to set up an international logistics system suitable to the local environment by providing corporations that deal in international commodities with value-added services, such as: shipping, distribution, storage, assembly, reprocessing, etc. The development of global logistics is becoming an important aspect of policy-making.

Previously, the various modes of international distribution have been classified into three categories, as determined by the different origins and destinations of conventional import-export cargo. These categories are: 1) transshipment mode, cargo is imported from abroad, and after being processed in logistics centers it is then dispersed to other foreign counties; 2) import mode: cargo is imported from abroad, and after being processed in a Distribution Center (DC) it is then dispersed within the country; 3) export mode: cargo is supplied domestically, and after being processed in DC it is then dispersed to foreign markets. Now from the viewpoint of systematic developments of international distribution systems, we can make the following modes of classification [23]: 1) traditional mode: domestic services for the regional dispersal and storage of cargo; 2) direct exchange mode: receiving cargo from and 
dispersing cargo to customers from worldwide, without establishing a DC; 3 ) transshipment mode: this involves domestic regional services for dispersing cargo, without stockpiling any cargo; 4) multinational mode: a DC is established linking various regions to organize the ordering of cargo, storage and dispersal of goods for adjacent locations.

For the classification of physical logistics management and services [1]: 1) basic services mode: provides public transit and storage services, without emphasizing the coordination and integration of distribution; 2) physical contract distribution services mode: provides contracted transit and storage services and permits the outsourcing of some of the distributed cargo, also allowing corporations to maintain substantial control over distribution; 3) management-contract distribution services mode: emphasizes the management of transit, storage and import-export of cargo; 4) integrated-contract distribution services mode: emphasizes the functional integration of physical logistics and management.

Fundamentally, logistics activity can be described as the process of increasing the value of cargo, from the raw material stage to the finished product. Thus, increasing the value of the processed cargo as much as possible is the ultimate goal in developing an international logistics system from the perspective of both private and public sectors.

The above-mentioned categories are based on the flow and the integration of logistics and management and these categories are merely an approximation, so they cannot adequately evaluate levels of increased value of logistics activity. Moreover, in the various stages and modes of logistics activity, each location has a unique set of circumstances. These regionally determined circumstances effect decisions regarding the suitable methods involved in the development of logistics.

Moreover, because the competition objects that airport face is different, there are several competitive relationships of international logistics activities, including international level (transshipment mode; reprocessing export mode), and domestic level (importexport; re-processing import mode). This paper will establish the international competitive level of airport location modes and analyze the suitable location mode of each airport.

\section{FUNCTIONS OF AN INTERNATIONAL LOGISTICS SYSTEM}

\section{Characteristics of international logistics}

The term "international logistics" refers to the exchange of cargo between two or more countries.
International distribution can be divided into physical supply and physical distribution. The former refers to the process of raw materials industries providing cargo for manufacturing industries. The later, conversely, refers to the process by which the manufacturing industry delivers the finished product to the consumer. In recent years, due to the varied and rapidly changing needs of consumers, low volume, high frequency and other diverse modes of delivery services have become necessary. The actual process of dispersing cargo has become one of the major challenges faced in the development of the international distribution of cargo. Figure 1 depicts the environment of international logistics activity [14].

The characteristics of international logistics are as stated below:

\section{(1) The supply market of international raw materials, semi- finished products and commodities}

In analyzing distribution it is important to consider the origin of commodities, the raw materials and semi-finished product that stimulate the international distribution market. At a DC, many semi-finished products go through addition fabrication and processing to become finished products. These finished products are then either dispersed to the international consumer market or sent on to an international, commercial DC, which acts as a transfer point for the dispersal of cargo. It is apparent that the geographical locations of raw material markets, commodities markets, and international logistics centers are key factors in the ability of cargo to reach other logistics centers in a timely fashion. Thus, international corporations stress geographic con-

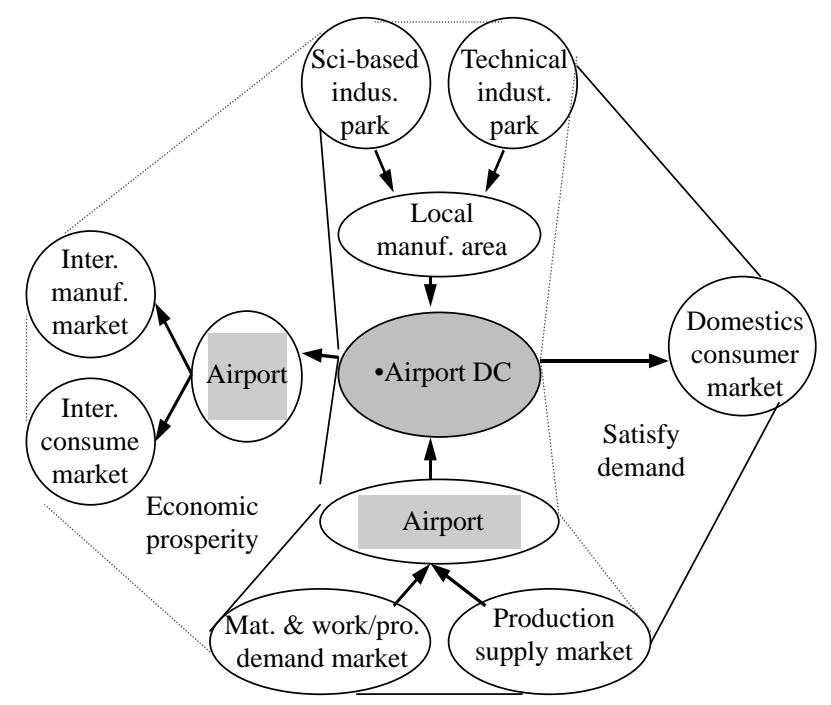

Fig. 1. The activity environment of international logistics. 
siderations when choosing a location to establish an International Distribution Center (IDC).

\section{(2) Airport conditions}

Airport is key hub locations for the transfer and dispersal of cargo in the international marketplace. Thus, environmental-geographical factors, such as the frequency of flights, the level of efficiency of an operating environment and the cost of transshipment are very influential. These factors may determine many important things, for example, whether or not the prime cost of the transshipment of cargo of a given DC is competitive, or the ability of given DC to satisfy consumers by dispersing cargo in a timely manner. Therefore, the conditions of a airport are vital factors in the development of IDC.

\section{(3) Local manufacturing area}

An important function of a DC is the additional fabrication, processing and packaging of semi-finished cargo together with similar activities that increase the value of cargo. Therefore, the characteristics of regional manufacturing industries located near given logistics centers, which may include science-based industrial parks capable of providing high-level support for increasing the deep value of cargo, or traditional industrial manufacturing area are key factors in the success of IDC parks, which also increase value at a more basic level, contribute to the efforts of logistics centers to increase the overall value of cargo. Product design and flexible manufacturing techniques are examples of such positive contributions of local

\section{(4) International consumer market}

The ultimate goal of international commodities distribution is to satisfy the needs of the costumers who compose the international consumer market. Thus, due to the needs for a small volume, varied and timely dispersal of cargo, the geographical location of international logistics centers and international consumer markets has become one of the major considerations made corporations in selecting prime locations to establish DC.

\section{(5) Local consumer markets}

International commerce makes use of international distribution in an effort to satisfy the needs of local consumers. This is also one of the major goals of the development of an international logistics system. Therefore, discovering how to understand the geographi- cal considerations of a local consumer market and the production capacity of a given region is an important step in developing an IDC.

\section{The modes of international logistics activity}

According to relevant references, competitiveness can be measured by the creation of value [20, 21, 22]. From this point of view, logistics systems may be viewed as value chain systems, measured by the creation of value. In the areas of international shipping, industry, economics, finance, culture, and environment, all regions have different backgrounds. As a result, in the course of development, all countries go through different stages and modes. In the case of the AsianPacific Zone, in the past few decades Hong Kong and Singapore have relied on their excellent harbor conditions, environmental advantages and strong economic foundations to transport great amounts of transit cargo. In addition, their finance and information services have performed remarkably, thereby attracting international corporations and establishing these regions as a global and Asian-Pacific operation headquarters.

Furthermore, Taiwan's highly competitive information and manufacturing industries have helped to establish its key position in the global information industry (Original Equipment Manufacturer, OEM). According to Toffler's third wave theory (agricultural era, industrial era, information era) [30], and Hope [13], "Competing in the 3rd Wave," production can be divided into three stages in the development of the three waves of increasing value: production capacity, prime cost, and the direction of value-added. This theory posits that production capacity should pursue an increase in the value of cargo.

From this perspective, this paper analyzes the role of intensive labor, intensive technology and intensive services in the purchase, shipping, storage, production, fabrication, examination, information, sale, and research of an international cargo and in establishing a value chain system. For this we may analyze and construct the model modes of regional development designating the two stages of transportation and production value-added, together with the four modes of import-export, transshipment, re-processing import and re-processing export (see Figure 2).

\section{Stage 1: Transportation value-added}

Through the integration of airports, airports and outside transportation systems the main function of this stage is to facilitate provide the function for transporting, warehousing and stocking functions. This stage includes the following modes: 


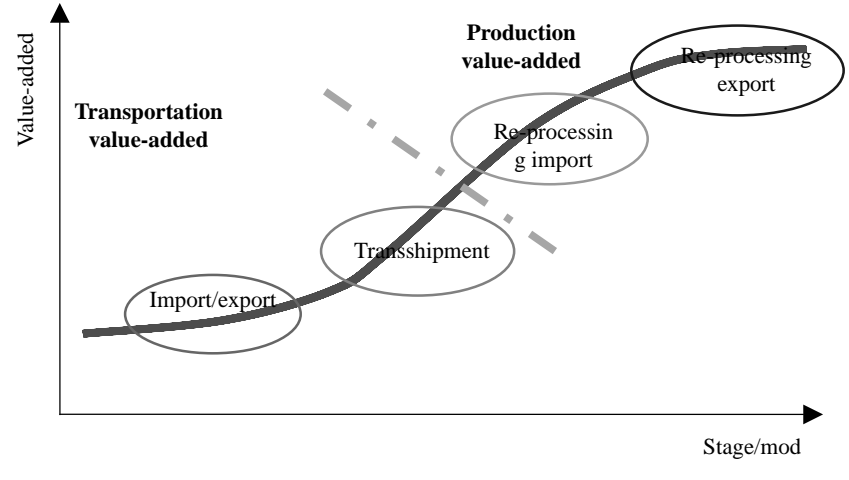

Fig. 2. The concept of two-stages and four-modes [14].

\section{(1) Mode 1: import-export mode}

Beginning at the airport, value-added services encompass only transporting, loading and discharging operations. For example of this form of distribution, we deal with the import of daily consumer items and the export of electronic cargo. This form is a beginning stage in the distribution process, providing traditional storage services, so the value added to products is relatively low.

\section{(2) Mode 2: Transshipment mode}

Airports with excellent geographic positioning, located on major flight lines, need less time to ship cargo to other airports. Thus, these airports have an opportunity to gradually become transshipment centers connecting different regions. Airlines companies that deal with distant regions first ship cargo to a hub airport, and the hub airport then acts as a feeder service for transferring cargo to nearby regional airports. Therefore, in addition to providing basic loading and discharging services, transit distribution also includes Multiple Countries Consolidation (MCC) services. For example, Hong Kong International Airport Transit Center deals with cargo from Mainland China, transferring it other airports. Transshipment centers, which are included in this category, traditionally provide for the storage of bonded cargo and the value-added potential of this mode is limited.

\section{Stage 2: Production value-added}

Through the integration of advanced and initial manufacturing industries, the main function of this stage is to provide the re-processing, examination, labeling, and other services that increase the value of cargo. This stage includes the following two modes:

\section{(3) Mode 3: Re-processing import mode}

The re-processing import mode is based on the use of key technology within the importing country, selecting semi-finished products, which can use a key technology, to import from aboard. After being processed and fabricated with new parts incorporating key technology the cargo is dispersed to domestic markets for local consumers. Furthermore, foreign access zones (FAZ), a concept established by the Japanese, could be established in a local area, where components and semifinished products may be more easily imported from abroad. The product can be processed using advanced local technology, and then dispersed to domestic markets. For example, imported PC shells, electric fans, and CPUs can be fitted to locally produced main-boards, CD-ROMs, radiators, etc. These can be fabricated and dispersed to local markets. In this way, services can be created to stimulate a high increase in value. In addition, this mode of logistics may ensure that competitive production techniques remain under domestic control.

\section{(4) Mode 4: Re-processing export mode}

In response to the rapid development of international logistics, international airports have been transformed from being airports specializing in the transshipment of cargo into ports that integrate the DC of cargo. In addition to providing basic storage together with the loading and discharging of cargo and MCC services, this mode of activity also includes the simple processing of cargo, packaging, labeling, dispersal, information management, etc. Through the re-processing export of cargo, this mode of activity increases the value of cargo.

\section{ANALYSIS OF LOCATION MODE INDICES}

\section{Evaluation criteria of location mode of airport DC}

The logistics ability (competition ability) measure can be divided into outcome-based and behavior-based capabilities/competencies [27]. The outcome-based competencies focus on the outcome of logistics (e.g. [8, $9,18,19])$. Researchers often consider these criteria as manufacturing strategies [10] and employ these items as performance criteria [26]. Here the outcome-based competencies are used to measure the performance, and the related references of criteria are shown in Table 1.

\section{Criteria acquisition}

According to the related references of measuring the logistics competition ability based on the outcome, 
Table 1. Outcome-based typology of logistics competencies

\begin{tabular}{|c|c|c|}
\hline $\begin{array}{l}\text { Author }(s) \\
\text { dimension competencies }\end{array}$ & & $\begin{array}{l}\text { Sub-dimension } \\
\text { of competencies }\end{array}$ \\
\hline $\begin{array}{l}\text { Fawcett, et al. }[8] \\
\text { Garvin }[11]\end{array}$ & Quality & $\begin{array}{l}\text { Performance, features, reliability, conformance, technical durability, } \\
\text { serviceability, aesthetics, perceived quality, humanity, value }\end{array}$ \\
\hline $\begin{array}{l}\text { Leong et al. [17]; } \\
\text { Slack [28] }\end{array}$ & Time & $\begin{array}{l}\text { Manufacturing lead time, rate of production introduction, deliver lead } \\
\text { time, due-date performance, frequency of delivery }\end{array}$ \\
\hline \multirow[t]{2}{*}{ Stalk [29] } & Cost & Manufacturing cost, value added, selling price, running cost, service cost \\
\hline & Flexibility & $\begin{array}{l}\text { Material quality, output quality, new product, modify product, } \\
\text { deliverability, volume, mix, resource mix }\end{array}$ \\
\hline \multirow[t]{4}{*}{ Dornier [7] } & Cost & Initial cost and lifecycle cost \\
\hline & Quality & Design quality and conformance quality \\
\hline & Service & Delivery speed and delivery reliability \\
\hline & Flexibility & New-product flexibility, customization, and product mix flexibility \\
\hline \multirow[t]{2}{*}{ Fawcett, et al. [9] } & Quality & Logistics quality nanufacturing quality \\
\hline & Cost & Logistics cost manufacturing cost \\
\hline
\end{tabular}

Source: Summarized from the literature and tabled by the author.

Table 2. The activities flow of international logistics system

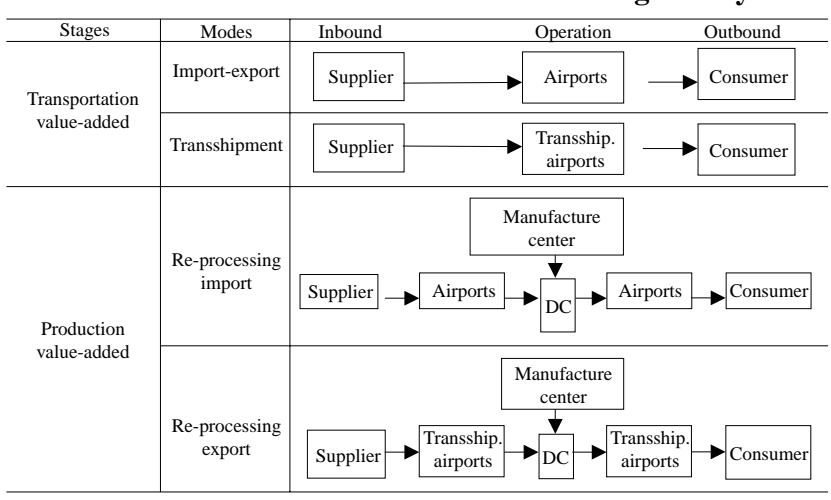

four competition dimensions are acquired: cost, time, quality and flexibility. To satisfy the users' (e.g. airlines or logistics operators) demands and to suit the business management scenario of international logistics, the four dimensions stated as above are utilized to develop the performance measure criteria. Owing to different performance measure situations should have different scenario considerations [2]. Herein, combining the function concept from "Competing in the 3rd Wave" and the classification standpoint of international logistics activity (Table 2), two kinds of performance measure criteria suitable for transshipment and re-processing export modes of international business practices can be obtained. The conversion process and adopted criteria are shown in Tables 3 and 4 .

\section{RESEARCH DESIGN AND METHODOLOGY}

\section{Questionnaire design and data collect}

This study conducts a survey on the core competitive factors of airport locations. The questionnaire method was used, and interviews were based on the research needs and survey principles (Table 5). This questionnaire has been created based on the design and survey principles to analyze the differences between the concerns of academic experts, logistics operators and airline managers. Through questionnaires and surveys the subjects use the comparative important scale to assign comparative importance of evaluation criteria based on their professional judgment. A total of 32 questionnaires were mailed to experts, logistics operators and airlines managers. Returned questionnaires totaled 13 (five academic experts, four logistics operators and four airline managers), and all 10 were considered valid. The return rate of questionnaires was $31.3 \%$.

\section{Research methodology}

This section introduces the research methods adopted to facilitate this paper.

\section{(1) Analytic hierarchy process}

The Analytic Hierarchy Process (AHP) [24] was 
Table 3. The transshipment mode indices conversion form

\begin{tabular}{|c|c|c|c|c|}
\hline Performance dimension & Cost & Time & Quality & Elasticity \\
\hline $\begin{array}{l}\text { Performance } \\
\text { sub-dimension }\end{array}$ & $\begin{array}{l}\text { - Initial cost } \\
\text { - Lifecycle cost } \\
\text { - Running cost } \\
\text { - Service cost }\end{array}$ & $\begin{array}{l}\text {-Supply chain } \\
\text { time } \\
\text {-Delivery lead } \\
\text { time } \\
\text {-Delivery speed }\end{array}$ & $\begin{array}{l}\text {-Humanity } \\
\text { - Responsiveness } \\
\text { to target markets } \\
\text {-Widespread } \\
\text { distribution coverage } \\
\text {-Selective distribution } \\
\text { coverage } \\
\text {-Delivery reliability }\end{array}$ & $\begin{array}{l}\text {-Deliverability } \\
\text {-Frequency of delivery } \\
\text { convenient }\end{array}$ \\
\hline $\begin{array}{l}\text { Demand-criteria } \\
\text { (Airline operators) }\end{array}$ & $\begin{array}{l}\text { - Transport cost } \\
\text { - Airplane in the airport cost } \\
\text { - Goods transport cost } \\
\text {-Empty goods of air } \\
\text { transport the cost } \\
\text { - Airline management cost }\end{array}$ & $\begin{array}{l}\text {-The inbound } \\
\text { transport time } \\
\text {-The outbound } \\
\text { transport time } \\
\text {-Air terminal } \\
\text { transport } \\
\text { efficiency }\end{array}$ & $\begin{array}{l}\text {-Humanity } \\
\text {-Provide the service } \\
\text { quality to source } \\
\text { market } \\
\text {-Transport operation } \\
\text { stability }\end{array}$ & $\begin{array}{l}\text { - Air terminal convenience } \\
\text { - Goods clearance convenience } \\
\text { - Outside conveyance of transportation } \\
\text { system } \\
\text { - The information handle the convenient } \\
\text { - Air terminal operation } \\
\text { liberalism degree }\end{array}$ \\
\hline $\begin{array}{l}\text { Supply-criteria } \\
\text { (Airport) }\end{array}$ & $\begin{array}{l}\text {-International } \\
\text { consumption market } \\
\text {-International } \\
\text { manufacturing market } \\
\text {-Air terminal fee rate } \\
\text { - Tax rate } \\
\text {-Import/export volume } \\
\text { - Transshipment volume }\end{array}$ & $\begin{array}{l}\text {-International } \\
\text { consumption } \\
\text { market } \\
\text {-International } \\
\text { manufacturing } \\
\text { market } \\
\text {-Clearance } \\
\text { efficiency }\end{array}$ & $\begin{array}{l}\text {-Political stability } \\
\text {-Economic stability } \\
\text {-Social stability } \\
\text {-Information ability }\end{array}$ & $\begin{array}{l}\text {-Information ability } \\
\text { - Clearance efficiency } \\
\text { - Management system }\end{array}$ \\
\hline
\end{tabular}

Table 4. The re-processing export mode indices conversion form

\begin{tabular}{|c|c|c|c|c|}
\hline Performance dimension & Cost & Time & Quality & Elasticity \\
\hline $\begin{array}{l}\text { Performance } \\
\text { sub-dimension }\end{array}$ & $\begin{array}{l}\text {-Initial cost } \\
\text { - Lifecycle cost } \\
\text { - Manufacturing cost } \\
\text { - Running cost } \\
\text { - Service cost }\end{array}$ & $\begin{array}{l}\text {-Delivery lead } \\
\text { time } \\
\text {-Product } \\
\text { development } \\
\text { cycle time } \\
\text {-Planned process } \\
\text { cycle time } \\
\text {-Delivery speed } \\
\text {-Manufacturing } \\
\text { lead time }\end{array}$ & $\begin{array}{l}\text { - Humanity } \\
\text {-Production design } \\
\text { quality } \\
\text {-Assemble the } \\
\text { components quality } \\
\text {-Supplier ability to } \\
\text { respond to quality } \\
\text { problems } \\
\text {-Delivery reliability }\end{array}$ & $\begin{array}{l}\text {-Technical durability } \\
\text { - Responsiveness to target market } \\
\text {-Widespread distribution coverage } \\
\text { - Capacity utilization } \\
\text { - New-product flexibility } \\
\text {-Delivery flexibility } \\
\text { - Frequency of delivery }\end{array}$ \\
\hline $\begin{array}{l}\text { Demand-criteria } \\
\text { (logistics operators) }\end{array}$ & $\begin{array}{l}\text { - Labor cost } \\
\text { - Taxes and levies cost } \\
\text { - Obtain the cost in the ware } \\
\text { - The logistics facilities } \\
\text { obtain the cost } \\
\text { - Transport cost } \\
\text { - Goods transport cost }\end{array}$ & $\begin{array}{l}\text { - Goods clearance } \\
\text { time } \\
\text {-Obtain time in } \\
\text { the ware } \\
\text {-The product } \\
\text { assemble the } \\
\text { efficiency } \\
\text {-Transport time } \\
\text { - Goods transport } \\
\text { efficiency }\end{array}$ & $\begin{array}{l}\text {-Humanity quality } \\
\text {-Product design ability } \\
\text {-Assemble the } \\
\text { components quality } \\
\text { - Re-export source } \\
\text { stability } \\
\text {-Transport homework } \\
\text { stability }\end{array}$ & $\begin{array}{l}\text {-Technique level } \\
\text {-Economic interior region scale } \\
\text { - The product assemble the ability } \\
\text { - Goods clearance convenience } \\
\text {-Information handle the convenient } \\
\text {-Operate enlargement }\end{array}$ \\
\hline $\begin{array}{l}\text { Supply-criteria } \\
\text { (Airport) }\end{array}$ & $\begin{array}{l}\text {-International consumption } \\
\text { market } \\
\text {-International } \\
\text { manufacturing market } \\
\text {-Air terminal fee rate } \\
\text {-Tax rate } \\
\text {-Add the worth tax rate } \\
\text {-Import/export volume } \\
\text {-Transshipment volume } \\
\text {-Wages levels }\end{array}$ & $\begin{array}{l}\text {-International } \\
\text { consumption } \\
\text { market } \\
\text {-International } \\
\text { manufacturing } \\
\text { market } \\
\text {-Clearance } \\
\text { efficiency }\end{array}$ & $\begin{array}{l}\text {-Political stability } \\
\text {-Economic stability } \\
\text {-Social stability } \\
\text { - Humanity quality } \\
\text {-Place industry } \\
\text { cluster effect }\end{array}$ & $\begin{array}{l}\text {-Information ability } \\
\text { - Clearance efficiency } \\
\text { - Management system } \\
\text {-Add the worth property the support } \\
\text { degree }\end{array}$ \\
\hline
\end{tabular}

initially presented by Saaty in 1980 for solving multiple criteria decision problems. Using a systematic hierar- chy structure, complex estimation criteria can be represented clearly and definitely. Ratio scales are utilized 
to make reciprocal comparisons for each element and each layer. After completing the reciprocal matrix, one can obtain comparative weights for each element. Considering the criteria $C_{1}, \ldots, C_{i}, \ldots, C_{j}, \ldots, C_{n}$, some one level in hierarchy. One wishes to find their weights of importance, $w_{1}, \ldots, w_{i}, \ldots, w_{j}, \ldots, w_{n}$, on some elements in the next level. Obtaining an exact priority vector $w$ $=\left(w_{1}, \ldots, w_{i}, \ldots, w_{j}, \ldots, w_{n}\right)$ is complex, so this paper uses the Normalization of Row Average (NRA) [25] method to replace the more complex operation. This method sums up each row element and standardizes it by summing all elements of the matrix. That is, allowing $a_{i j}, i$, $j=1,2, \ldots, n$, to be the importance strength of $C_{i}$ when compared with $C_{j}$, then

$$
w_{i}=\frac{\sum_{j=1}^{n} a_{i j}}{\sum_{i=1}^{n} \sum_{j=1}^{n} a_{i j}}, i=1,2, \ldots, n
$$

Generally, we can represent the comparative importance scale of criteria as shown in Table 5.

Consistency testing is an important issue for using Eq. (1) to find the priority vector and it contains two layers. One is to check whether the pairwise comparative matrix which answers by decision makers is a consistency matrix or not. The other is to check the consistency of hierarchy structure. The ratio to estimate the consistency is Consistent Ratio (CR). The CR tells us how consistent we are with our answers. A higher number means we are less consistent, while a lower number means that we are more consistent. In general, if the CR is less than or equal to 0.1 , the consistency will be guaranteed. The ratio is equal to the consistency index (CI) divided by the random index (RI).

$$
\mathrm{CR}=\frac{\mathrm{CI}}{\mathrm{RI}}
$$

The formula for C.I. is:

$$
\text { C.I. }=\frac{\lambda-n}{n-1}
$$

$n$ is the number of items being compared. The value for $\lambda$ is simple the average value of the consistency vector. The random index is a direct function of the number of alternatives.

Due to the pairwise comparisons utilized in AHP facilitate the conveyance of responsors' preference, and the measure of consistency enables us to return to the judgments modifying them here and there to improve the overall consistency. The AHP method will be utilized to find the criteria weight for each level.

\section{Fuzzy set theory}

In a universe of discourse of $X$, a fuzzy subset $A$ of $X$ is characterized by a membership function $f_{A}$, which maps each element $x$ in $X$ to a real number in the interval $[0,1]$. The function value represents the grade of membership of $x$ in A. A fuzzy number A $[6,7,16]$ in $\Re$ (real line) is a triangular fuzzy number if its membership function $f_{A}: \Re \rightarrow[0,1]$ is

$$
f_{A}(x)= \begin{cases}\frac{x-c}{a-c}, & c \leq x \leq a \\ \frac{d-x}{d-a}, & a \leq x \leq d \\ 0, & \text { otherwise }\end{cases}
$$

With $-\infty<c \leq a \leq d<\infty$, the triangular fuzzy number A can be represented by $(c, a, d)$. Here, the triangular fuzzy numbers are used to denote the approximate reasoning of linguistic values [32]. They are used to covey the subjective evaluation of decisionmakers. The reason of using triangular fuzzy number is that it is easy to use. For example, "weight" is a linguis-

\begin{tabular}{|c|c|}
\hline Principles & Description \\
\hline Questionnaire purpose & Introduce the purpose of questionnaire and descript the based theory for the pairwise comparisons. \\
\hline and measure criteria & $\begin{array}{l}\text { And computes the weighting factors and evaluation of two-stage (four modes) logistics system } \\
\text { measure criteria. }\end{array}$ \\
\hline $\begin{array}{l}\text { The measure basis for } \\
\text { relative importance value }\end{array}$ & $\begin{array}{l}\text { With the pairwise comparisons matrix evaluation for each mode, we start by listing the factors } \\
\text { and their relation value on a scale } 1 \text { to } 9 .\end{array}$ \\
\hline Questionnaire sample & In Taiwan \\
\hline According to various & Logistics operators, airlines managers, and experts. \\
\hline $\begin{array}{l}\text { stages and modes } \\
\text { separate consideration }\end{array}$ & $\begin{array}{l}\text { Due to the differences types for international logistics, involving various location factors. Thus, } \\
\text { questionnaire survey for measure criteria must be separated to evaluate. }\end{array}$ \\
\hline
\end{tabular}
tic variable, its values are very low, low, medium, high, very high, etc. Linguistic value can also be represented

Table 5. The questionnaire design and survey principles 
by the approximate represented by the approximate reasoning of fuzzy set theory. For example, the linguistic value "Good" can be denoted by $(0.5,0.7,1)$. An exact number "a" can be represented by $(a, a, a)$. In this paper the linguistic values are utilized to assess the linguistic ratings given by decision-makers, as well as the linguistic weights assigned to various selection criteria. By the extension principle [31] the extended algebraic operations of any two triangular fuzzy numbers $A_{1}=\left(c_{1}, a_{1}, d_{1}\right), A_{2}=\left(c_{2}, a_{2}, d_{2}\right)$ can be expressed as:

$$
\begin{aligned}
& A_{1} \oplus A_{2}=\left(c_{1}+c_{2}, a_{1}+a_{2}, d_{1}+d_{2}\right) ; \\
& K \otimes A_{1}=\left(k c_{1}, k a_{1}, k d_{1}\right), k \in R, k \geq 0 .
\end{aligned}
$$

\section{Ranking of triangular fuzzy numbers}

Many fuzzy ranking methods have been proposed $[3,4,15]$. Because of the graded mean integration representation method [5] not only improve some drawbacks of the existing method, but also possess the advantage of easy implementation, and powerfulness in problem solving, it will be used to rank the final superiority ratings of all alternatives.

Let $A_{i}=\left(c_{i}, a_{i}, d_{i}\right), i=1,2, \cdots, n$, be $n$ triangular fuzzy numbers. The graded mean integration representation $R\left(A_{i}\right)$ of is

$$
R\left(A_{i}\right)=\frac{c_{i}+4 a_{i}+d_{i}}{6}
$$

Let $R\left(A_{i}\right)$ and $R\left(A_{j}\right)$ be respectively the graded mean integration representations of triangular fuzzy numbers $A_{i}$ and $A_{j}$. Defined that

$$
\begin{aligned}
& A_{i}>A_{j} \Leftrightarrow R\left(A_{i}\right)>R\left(A_{j}\right) ; \\
& A_{i}=A_{j} \Leftrightarrow R\left(A_{i}\right)=R\left(A_{j}\right) ; \\
& A_{i}<A_{j} \Leftrightarrow R\left(A_{i}\right)<R\left(A_{j}\right),
\end{aligned}
$$

\section{Measure for linguistic value}

The concept of linguistic value [32] is useful in describing situations that are complex or poorly defined by quantitative expressions. Linguistic value can be represented by the approximate reasoning of fuzzy set theory. Define the linguistic values set $\mathrm{S}=\{\mathrm{VG}, \mathrm{G}, \mathrm{M}$, $\mathrm{B}, \mathrm{VB}\}$, where $\mathrm{VG}=$ Very Good, $\mathrm{G}=$ Good, $\mathrm{M}=$ Medium, $\mathrm{B}=\mathrm{Bad}, \mathrm{VB}=$ Very Bad. Here, the linguistic values in sets $S$ are used by the decision-makers to evaluate the suitability of alternative versus various criteria above the alternative level. The membership function of each linguistic value is defined as: $V G=$
$(0.7,1,1), \mathrm{G}=(0.5,0.7,1), \mathrm{M}=(0.2,0.5,0.8), \mathrm{B}=(0$, $0.3,0.5)$ and $\mathrm{VB}=(0,0,0.3)$.

\section{OPTIMAL LOCATION MODE OF INTERNATIONAL LOGISTICS}

In this section, a systematic fuzzy MCDM model for the optimal location mode of international logistics on airport competition evaluation is proposed. The steps can be summarized as follows:

Step 1: Form a committee of decision-makers and select the evaluation criteria.

Step 2: Develop a hierarchical structure of best location mode evaluation.

Step 3: Use the AHP method to obtain the criteria weight for each level.

Step 4: Use the weights obtained by step 3 to determine the integrated weights of all sub-criteria above the alternative level.

Step 5: Tabulate the linguistic evaluation values assigned to the alternatives by the decisionmakers; then poll them to obtain the aggregated fuzzy scores of all alternatives under each criterion above the alternative level.

Step 6: Use the formula (5) to find the representation values of the aggregated fuzzy ratings of all alternatives.

Step 7: Find superiority ratings of all alternatives versus various sub-criteria and obtain the suitable location mode for airports in international logistics.

\section{Develop a hierarchical structure of best location mode evaluation}

In order to concentrate the similar criteria and facilitate the implementation of weights evaluation and superiority ratings of alternatives, the criteria shown in Tables 3 and 4 are integrated again. In addition, the integrated evaluation criteria of transshipment mode and re-processing export mode are shown in Tables 6 and 7 , respectively. And, the hierarchical structure of transshipment mode and re-processing export mode are shown in Figures 3 and 4.

\section{Use AHP method to obtain the criteria weight for each level}

Through questionnaires and surveys, the comparative importance value for evaluation criteria of weights obtained by the FAHP method, and weights of subcriteria versus objective which weight of dimension multiply by weight of sub-criteria can be obtained, as shown in Tables 8 and 9. 
Table 6. Means of evaluation criteria for transshipment mode

\begin{tabular}{|c|c|c|}
\hline Dimension & Sub-criteria & Description \\
\hline \multirow{2}{*}{$\begin{array}{l}\text { International } \\
\text { market location }\end{array}$} & $\begin{array}{l}\text { International } \\
\text { consumption market }\end{array}$ & $\begin{array}{l}\text { The transportation distance from the airport to the international consumer markets has a significant } \\
\text { effect on the transportation cost and delivery time. }\end{array}$ \\
\hline & $\begin{array}{l}\text { International } \\
\text { manufacturing market }\end{array}$ & $\begin{array}{l}\text { The transportation distance from the major international manufacturing markets to the airport has } \\
\text { a significant effect on the transportation cost and delivery time. }\end{array}$ \\
\hline \multirow{3}{*}{$\begin{array}{l}\text { National } \\
\text { stability }\end{array}$} & Political stability & $\begin{array}{l}\text { The political stability (both domestic and foreign relations) has a direct bearing on the overall } \\
\text { stability with which airlines operate within the airport. }\end{array}$ \\
\hline & Economic stability & $\begin{array}{l}\text { The stability of the economic systems and transportation policies (e.g. autonomous management } \\
\text { of the airline, level of openness in allowing diverse operations) also has a direct bearing on the } \\
\text { overall stability in which airlines operate within the airport. }\end{array}$ \\
\hline & Social stability & $\begin{array}{l}\text { The stability of the society (e.g. frequency of work strikes) directly affects the overall stability with } \\
\text { which airlines operate at the airport. }\end{array}$ \\
\hline \multirow{5}{*}{$\begin{array}{l}\text { Airport } \\
\text { operation and } \\
\text { management }\end{array}$} & Air terminal fee rate & Airport rates affect the cost of airline operations and cargo at the airport. \\
\hline & Tax rate & Tax privileges offered by the government directly affect the cost of airline operations at the airport. \\
\hline & Clearance efficiency & The clearance efficiency affects the time spent by airplanes and goods at the airport. \\
\hline & Management system & $\begin{array}{l}\text { The airport management system (e.g. availability of time slots of) affects the airport costs of } \\
\text { airlines. }\end{array}$ \\
\hline & Information ability & $\begin{array}{l}\text { The level of computerization at the airport affects the length of time that planes and shipments } \\
\text { stay at the airport, as well as the efficiency of airline management. }\end{array}$ \\
\hline \multirow{2}{*}{ Economic scale } & Import/export volume & The volume of imports and exports handled by the airport affects the average handling \\
\hline & Transship volume & Ime of transhipments at the airport affects the average handling costs. \\
\hline
\end{tabular}

Table 7. Means of evaluation criteria for re-processing export mode

\begin{tabular}{|c|c|c|}
\hline Dimension & Sub-criteria & Description \\
\hline \multirow{2}{*}{$\begin{array}{l}\text { International } \\
\text { market location }\end{array}$} & $\begin{array}{l}\text { International } \\
\text { consumption market }\end{array}$ & $\begin{array}{l}\text { The transportation distance from the airport to the international consumer markets has a significant } \\
\text { effect on the transportation cost and delivery time. }\end{array}$ \\
\hline & $\begin{array}{l}\text { International } \\
\text { Manufacturing market }\end{array}$ & $\begin{array}{l}\text { Transportation distance from the major international manufacturing markets to the airport has } \\
\text { a significant effect on the transportation cost and delivery time. }\end{array}$ \\
\hline \multirow{3}{*}{$\begin{array}{l}\text { National } \\
\text { stability }\end{array}$} & Political stability & $\begin{array}{l}\text { The political stability (both domestic and foreign relations) has a direct bearing on the overall } \\
\text { stability with which airlines operate within the airport. }\end{array}$ \\
\hline & Economic stability & $\begin{array}{l}\text { The stability of the economic systems and transportation policies (e.g. autonomous management } \\
\text { of the airline, level of openness in allowing diverse operations) also has a direct bearing on the } \\
\text { overall stability in which airlines operate within the airport. }\end{array}$ \\
\hline & Social stability & $\begin{array}{l}\text { The stability of the society (e.g. frequency of work strikes) directly affects the overall stability with } \\
\text { airlines operate at the airport. }\end{array}$ \\
\hline \multirow{5}{*}{$\begin{array}{l}\text { Airport } \\
\text { operation and } \\
\text { management }\end{array}$} & Air terminal fee rate & Airport rates affect the cost of airline's operations and cargo at the airport. \\
\hline & Tax rate & Tax privileges offered by the government directly affect the cost of airline operation at the airport. \\
\hline & Clearance efficiency & The clearance efficiency affects the time spent by airplanes and goods at the airport. \\
\hline & Management system & The airport management system (e.g. availability of time slots) affects the airport costs of airlines. \\
\hline & Information ability & $\begin{array}{l}\text { The level of computerization at the airport affects the length of time that planes and shipments stay } \\
\text { at the airport, as well as the efficiency of airline management. }\end{array}$ \\
\hline \multirow{2}{*}{ Economic scale } & I/E volume & The volume of imports and exports handled by the airport affects the average handling costs \\
\hline & Transship volume & The volume of transhipments at the airport affects the average handling costs. \\
\hline \multirow{5}{*}{$\begin{array}{l}\text { Re-processing } \\
\text { support }\end{array}$} & Human quality & Refers to the effect of the human quality on the industry. \\
\hline & $\begin{array}{l}\text { Degree of support } \\
\text { from hi-tech industries }\end{array}$ & $\begin{array}{l}\text { Refers to the effect that the level of support from preliminary, mid-range, and in-depth processing } \\
\text { industries has on the desire of the logistics business owner to process his goods. }\end{array}$ \\
\hline & $\begin{array}{l}\text { Industry clustering } \\
\text { ability }\end{array}$ & $\begin{array}{l}\text { Upstream and downstream, vertical, and parallel integration between industries (e.g. } \\
\text { establishment of free trade zones) affects the desire of the logistics business owner to process } \\
\text { his goods. }\end{array}$ \\
\hline & Wage level & Wage levels affect the desire of the logistics operator to process goods. \\
\hline & Add-valued tax rate & The rate of value-added taxes affects the logistics operator. \\
\hline
\end{tabular}




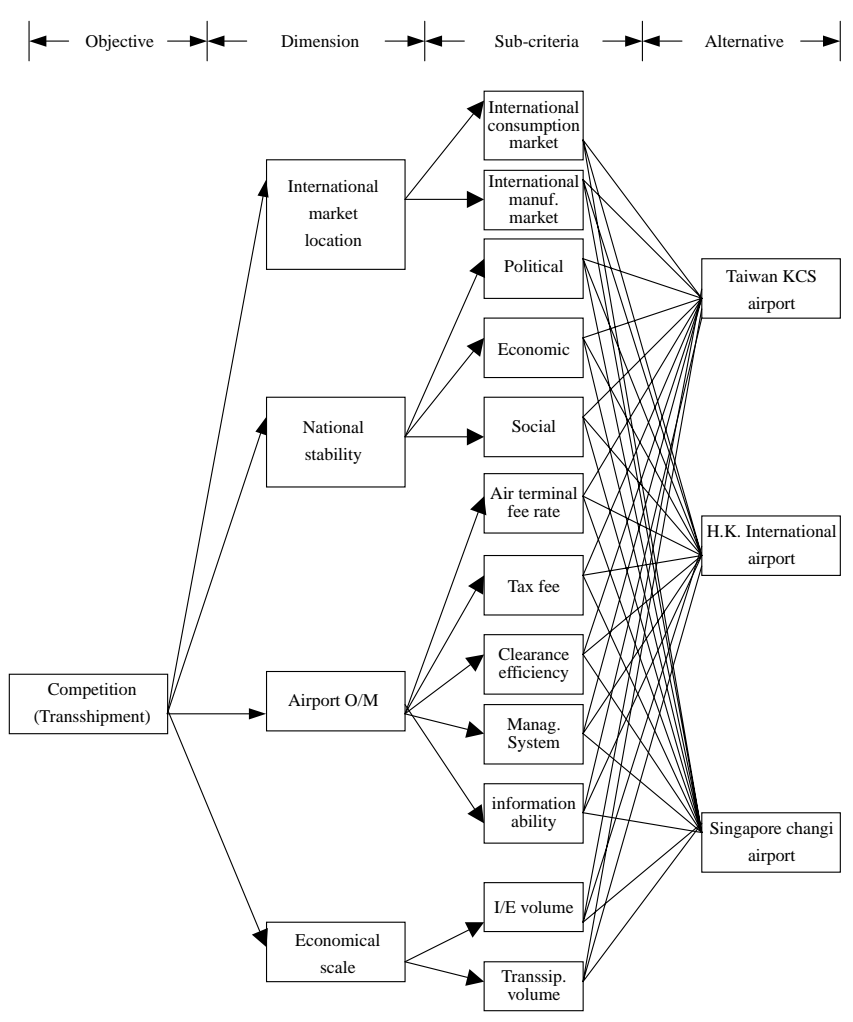

Fig. 3. The hierarchical structure of the transshipment mode of international logistics.

\section{Find aggregated fuzzy scores of all alternatives under each criterion above the alternative level}

The subjects utilize the linguistic rating set $\mathrm{S}=$ $\{\mathrm{VG}, \mathrm{G}, \mathrm{M}, \mathrm{B}, \mathrm{VB}\}$ to evaluate the superiority of all alternatives under each of the sub-criteria above the alternative level. Combining the integrated weights of

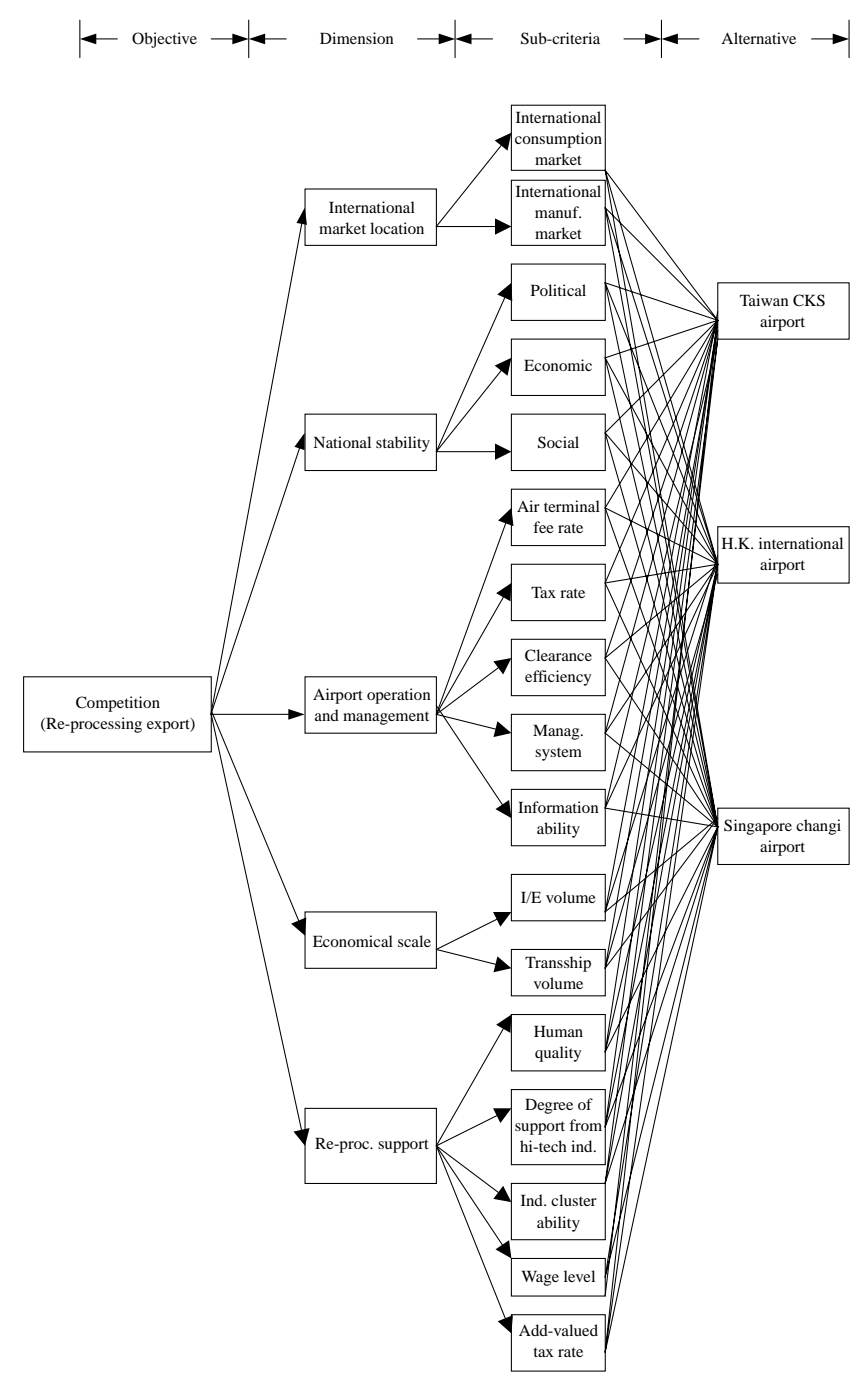

Fig. 4. The hierarchical structure of the re-processing export mode of international logistics.

Table 8. Criteria weights of the transshipment mode

\begin{tabular}{llllc}
\hline Dimension & Weight & \multicolumn{1}{c}{ Sub-criteria } & Weight & Weight of sub-criteria versus objective \\
\hline $\begin{array}{l}\text { International market } \\
\text { location }\end{array}$ & \multirow{2}{*}{0.3508} & International consumption market & 0.7239 & 0.2539 \\
& & International Manufacturing market & 0.2761 & 0.0969 \\
\hline \multirow{2}{*}{ National stability } & \multirow{2}{*}{0.2426} & Political stability & 0.4428 & 0.1074 \\
& & Economic stability & 0.4143 & 0.1007 \\
& & Social stability & 0.1429 & 0.0345 \\
\hline \multirow{2}{*}{$\begin{array}{l}\text { Airport operation } \\
\text { and management }\end{array}$} & \multirow{2}{*}{0.2117} & Air terminal fee rate & 0.2257 & 0.0477 \\
& & Tax rate & 0.2977 & 0.0629 \\
& & Clearance efficiency & 0.1679 & 0.0355 \\
& & Management system & 0.115 & 0.0243 \\
Economical scale & \multirow{2}{*}{0.1949} & Information ability & 0.1937 & 0.0413 \\
\hline & Transship volume & 0.1747 & 0.0341 \\
\hline
\end{tabular}


Table 9. Criteria weights of the Re-processing export mode

\begin{tabular}{|c|c|c|c|c|}
\hline Dimension & Weight & Sub-criteria & Weight & Weight of sub-criteria versus objective \\
\hline \multirow{2}{*}{$\begin{array}{l}\text { International market } \\
\text { location }\end{array}$} & \multirow[t]{2}{*}{0.0820} & International consumption market & 0.2193 & 0.0180 \\
\hline & & International manufacturing market & 0.7807 & 0.0640 \\
\hline \multirow{3}{*}{ National stability } & \multirow{3}{*}{0.1526} & Political stability & 0.2145 & 0.0327 \\
\hline & & Economic stability & 0.5124 & 0.0782 \\
\hline & & Social stability & 0.2731 & 0.0417 \\
\hline \multirow{5}{*}{$\begin{array}{l}\text { Airport operation } \\
\text { and management }\end{array}$} & \multirow{5}{*}{0.1175} & Air terminal fee rate & 0.1440 & 0.0169 \\
\hline & & Tax rate & 0.1387 & 0.0163 \\
\hline & & Clearance efficiency & 0.2138 & 0.0251 \\
\hline & & Management system & 0.2677 & 0.0315 \\
\hline & & Information ability & 0.2359 & 0.0277 \\
\hline \multirow[b]{2}{*}{ Economical scale } & \multirow[b]{2}{*}{0.2943} & $\mathrm{I} / \mathrm{E}$ volume & 0.2885 & 0.0849 \\
\hline & & Transship volume & 0.7115 & 0.2094 \\
\hline \multirow{5}{*}{$\begin{array}{l}\text { Re-processing } \\
\text { support }\end{array}$} & \multirow{5}{*}{0.3536} & Human quality & 0.1641 & 0.0580 \\
\hline & & Degree of support from Hi-tech industries & 0.3445 & 0.1218 \\
\hline & & Industry clustering ability & 0.2046 & 0.0724 \\
\hline & & Wage level & 0.1422 & 0.0503 \\
\hline & & Add-valued tax rate & 0.1445 & 0.0511 \\
\hline
\end{tabular}

Table 10. Aggregated fuzzy scores of all alternatives under sub-criteria of transshipment mode

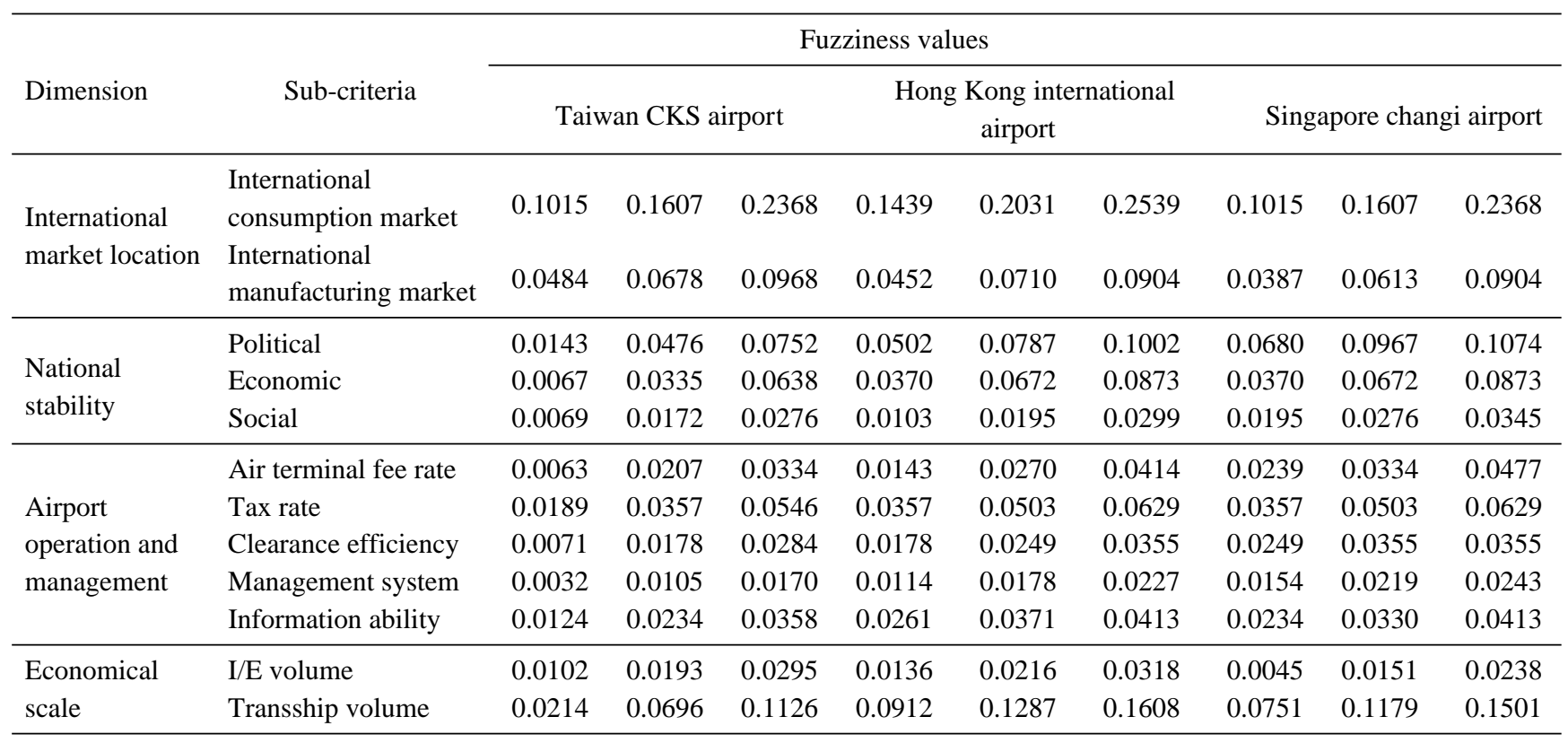

all sub-criteria and representation values of the aggregated fuzzy ratings of all alternatives. The results are shown in Tables 10 and 11.

\section{Representation values of the aggregated fuzzy ratings of all alternatives}

By adding all the aggregated fuzzy scores of each alternative under each of the sub-criteria, the represen- tation values of each alternative will be obtained (Table 12).

\section{Suitable airport modes in international logistics}

Then, the formula (5) is utilized to find superiority ratings of all alternatives versus various sub-criteria and obtain the suitable location mode for airports in international logistics. The result is shown in Table 13. 
Table 11. Aggregated fuzzy scores of all alternatives under sub-criteria of re-processing export mode

\begin{tabular}{|c|c|c|c|c|c|c|c|c|c|c|}
\hline \multirow{4}{*}{$\begin{array}{l}\text { Dimension } \\
\begin{array}{l}\text { International } \\
\text { market location }\end{array}\end{array}$} & \multirow{4}{*}{$\begin{array}{l}\text { Sub-criteria } \\
\text { ernational } \\
\text { nsumption market } \\
\text { ernational } \\
\text { inufacturing market }\end{array}$} & \multicolumn{9}{|c|}{ Fuzziness values } \\
\hline & & \multicolumn{3}{|c|}{ Taiwan CKS airport } & \multicolumn{3}{|c|}{$\begin{array}{c}\text { Hong Kong international } \\
\text { airport }\end{array}$} & \multicolumn{3}{|c|}{ Singapore changi airport } \\
\hline & & 0.0072 & 0.0114 & 0.0168 & 0.0054 & 0.0102 & 0.0156 & 0.0072 & 0.0114 & 0.0168 \\
\hline & & 0.0320 & 0.0448 & 0.0640 & 0.0128 & 0.0320 & 0.0512 & 0.0192 & 0.0363 & 0.0555 \\
\hline \multirow{3}{*}{$\begin{array}{l}\text { National } \\
\text { stability }\end{array}$} & Political & 0.0000 & 0.0098 & 0.0164 & 0.0186 & 0.0262 & 0.0327 & 0.0000 & 0.0098 & 0.0164 \\
\hline & Economic & 0.0156 & 0.0391 & 0.0626 & 0.0443 & 0.0626 & 0.0782 & 0.0313 & 0.0495 & 0.0730 \\
\hline & Social & 0.0000 & 0.0055 & 0.0185 & 0.0208 & 0.0292 & 0.0417 & 0.0083 & 0.0208 & 0.0333 \\
\hline \multirow{5}{*}{$\begin{array}{l}\text { Airport } \\
\text { operation and } \\
\text { management }\end{array}$} & Air terminal fee rate & 0.0051 & 0.0096 & 0.0147 & 0.0085 & 0.0118 & 0.0169 & 0.0023 & 0.0073 & 0.0118 \\
\hline & & 0.0022 & 0.0072 & 0.0114 & 0.0022 & 0.0072 & 0.0114 & 0.0060 & 0.0109 & 0.0141 \\
\hline & Clearance efficiency & 0.0000 & 0.0033 & 0.0111 & 0.0050 & 0.0126 & 0.0201 & 0.0100 & 0.0159 & 0.0234 \\
\hline & Management system & 0.0042 & 0.0139 & 0.0220 & 0.0157 & 0.0220 & 0.0315 & 0.0126 & 0.0199 & 0.0293 \\
\hline & Information ability & 0.0037 & 0.0123 & 0.0194 & 0.0139 & 0.0194 & 0.0277 & 0.0083 & 0.0157 & 0.0240 \\
\hline \multirow{4}{*}{$\begin{array}{l}\text { Economical } \\
\text { scale }\end{array}$} & I/E volume & 0.0340 & 0.0538 & 0.0792 & 0.0397 & 0.0622 & 0.0792 & 0.0397 & 0.0622 & 0.0792 \\
\hline & Transship volume & 0.0000 & 0.0278 & 0.0928 & 0.0628 & 0.1256 & 0.1606 & 0.0838 & 0.1325 & 0.1954 \\
\hline & Humanity quality & 0.0290 & 0.0406 & 0.0580 & 0.0116 & 0.0290 & 0.0464 & 0.0116 & 0.0290 & 0.0464 \\
\hline & $\begin{array}{l}\text { Degree of support } \\
\text { from hi-tech industries }\end{array}$ & 0.0569 & 0.0893 & 0.1137 & 0.0244 & 0.0609 & 0.0975 & 0.0000 & 0.0365 & 0.0609 \\
\hline \multirow[t]{3}{*}{$\begin{array}{l}\text { Re-processing } \\
\text { support }\end{array}$} & $\begin{array}{l}\text { Industry clustering } \\
\text { ability }\end{array}$ & 0.0410 & 0.0579 & 0.0724 & 0.0169 & 0.0362 & 0.0555 & 0.0000 & 0.0217 & 0.0362 \\
\hline & Wage level & 0.0251 & 0.0352 & 0.0503 & 0.0000 & 0.0151 & 0.0251 & 0.0000 & 0.0151 & 0.0251 \\
\hline & Add-valued tax rate & 0.0204 & 0.0323 & 0.0477 & 0.0068 & 0.0221 & 0.0358 & 0.0000 & 0.0153 & 0.0255 \\
\hline
\end{tabular}

Table 12. Representation values of the aggregated fuzzy ratings

\begin{tabular}{lcc}
\hline \multirow{2}{*}{ Location mode } & \multicolumn{2}{c}{ Representation values } \\
\cline { 2 - 3 } & Transshipment & Re-processing export \\
\hline Taiwan CKS airport & $(0.2574,0.4542,0.8115)$ & $(0.2764,0.4940,0.7708)$ \\
Hong Kong international airport & $(0.4967,0.7470,0.9580)$ & $(0.2402,0.5100,0.7665)$ \\
Singapore changi airport & $(0.4676,0.7205,0.9420)$ & $(0.3093,0.5843,0.8271)$ \\
\hline
\end{tabular}

Table 13. The suitable airport modes of the airport DC

\begin{tabular}{lccc}
\hline Location mode & Transshipment total score & Re-processing export total score & Suitable location mode \\
\hline Taiwan CKS airport & 0.4801 & 0.5039 & Re-processing export \\
Hong Kong international airport & 0.7405 & 0.4678 & Transshipment \\
Singapore changi airport & 0.7153 & 0.5789 & Re-processing export, transshipment \\
\hline
\end{tabular}

\section{Analyses for location modes}

Based on the aggregated fuzzy scores of alternatives shown in Table 10 in the area of transshipment, Taiwan's CKS Airport has the advantage in the interna- tional manufacturing markets, while the Hong Kong International Airport has the advantage in international consumer markets, economic stability, tax rates, information ability, import-export volume, and transship volume; Singapore's Changi Airport shows a distinct 
advantage in the areas of political stability, social stability, air terminal fee rate, tax rates, clearance efficiency, and management system. Similarly, based on the anticipated results (as shown in Table 11) in the area of re-processing export, Taiwan's CKS Airport has the advantage in international manufacturing markets, human quality, degree of support from hi-tech industries, industry clustering ability, wage level, and add-valued tax rates. The Hong Kong International Airport has the advantage in international consumption markets and import-export volume; Singapore's Changi Airport shows a distinct advantage in the areas of political stability, economic stability, social stability, air terminal fee rate, tax rates, clearance efficiency, management system, information ability, and transshipment volume. In Table 13, the top two location modes with the highest anticipated values have been chosen as the suitable airport modes. In terms of ranking, Taiwan's CKS Airport is suitable for reprocessing export (refers to in-depth processing) mode; Hong Kong International Airport is suitable for development of the transshipment mode; Singapore's Changi Airport is suitable for development of the re-processing export (refers to preliminary processing) and transshipment modes.

\section{CONCLUSION}

Implications identified from this study can be summarized as follow: First, different airports will prove to be superior for the implementation of specific logistic functions. This paper chooses the competitive criteria of the airport modes and makes a competitive evaluation based on the characteristics of each airport. Second, because the suitable mode for the international logistics development of each airport is different. Through the results of the FAHP calculations, the top two airport modes with the highest anticipated values have been chosen as the modes for the development of logistics activities. In terms of rankings, Taiwan's CKS Airport is suitable for developing the re-processing export mode; the Hong Kong International Airport is suitable for developing the transshipment mode; and Singapore's Changi Airport is suitable for developing the re-processing export (refers to preliminary processing) and transshipment modes. Third, different airports will prove to identify suit airport modes for developing international logistics activities in airports in terms of international competitive status in the areas of transshipment and re-processing export. However, this paper does not explore the domestic competitive status of import-export and re-processing import on airport. Consequently, future research may focus on these two areas.

\section{REFERENCES}

1. Africk, J.M. and Calkins, C.S., "Does Asset Ownership Mean Better Service?" Transportation and Distribution, May, pp. 49-61 (1994).

2. Andy, N., Mike, G., and Ken, P., "Performance Measurement System Design," International Journal of Operations \& Production Management, Vol. 15, No. 4, pp. 80-116 (1995).

3. Bortolan, G. and Degani, R., "A Review of Some Method for Ranking Fuzzy Subsets," Fuzzy Sets and Systems, Vol. 15, pp. 1-19 (1985).

4. Campos, L.M. and Gonzalez, A., "A Subjective Approach for Ranking Fuzzy Numbers," Fuzzy Sets and Systems, Vol. 29, pp. 145-153 (1989).

5. Chen, S.H. and Hsieh, C.H., "Representation, Ranking, Distance, and Similarity of L-R Type Fuzzy Number and Application," Australian Journal of Intelligent Processing Systems, Vol. 6, No. 4, pp. 217-229 (2000).

6. Dubois, D. and Prade, H., "Operations on Fuzzy Number,” The International Journal of Systems Science, Vo 19, pp. 613-626 (1978).

7. Dornier, P.P., Ernst, R., Fender, M., and Kouveilis, P., Global Operation and Logistics, John Wiley \& Son Inc., New York (1998).

8. Fawcett, S.E., Calantone, R., and Smith, S.R., “An Investigation of the Impact of Flexibility on Global Reach and Firm Performance," Journal of Business Logistics, Vol. 17, No. 2, pp. 167-196 (1996).

9. Fawcett, S.E., Calantone, R.J., and Roath, A., "Meeting Quality and Cost Imperatives in a Global Market," International Journal of Physical Distribution and Logistics Management, Vol. 30, No. 6, pp. 472-499 (2000).

10. Frohlich, M.T. and Dixon, J.R., "A Taxonomy of Manufacturing Strategies Revisited," Journal of Operations Management, Vol. 19, No. 5, pp. 541-558 (2001).

11. Garvin, D.A., "Competing on the Eight Dimension of Quality," Harvard Business Review, Nov-Dec, pp. 101209 (1987).

12. Gerwin, D.A., "An Agenda of Research on the Flexibility of Manufacturing Processes," International Journal of Operations \& Production Management, Vol. 7, No. 1, pp. 45-52 (1987).

13. Hope, T., Competing in the 3rd Wave: the Ten Key Management Issues of the Information Age, Harvard Business School Press, Boston, MA (1997).

14. Huang, W.C., Wu, S.C., Teng, J.Y., and Lee, K.L., "Modeling the Optimal Mode Split for Freight Transportation in Taiwan Area from the Viewpoint of Modal shift," Proceedings of the Eastern Asia Society for Transportation Studies, Vol. 3, No. 3, pp. 1-16 (2001).

15. Kim, K. and Park, K.S., "Ranking Fuzzy Numbers with Index of Optimism," Fuzzy Sets and Systems, Vol. 35, pp. 143-150 (1990). 
16. Laarhoven, P.J.M., “A Fuzzy Extension of Saaty's Priority Theory," Fuzzy sets and Systems, Vol. 11, pp. 229241 (1983).

17. Leong, G.K., Snyder, D.L., and Ward, P.T., "Research in the Process and Content of Manufacturing Strategy", OMEGA International Journal of Management Science, Vol. 18, No. 2, pp. 109-122 (1990).

18. Morash, E.A., Droge, C., and Vickery, S.K., "Boundary Spanning Interfaces Between Logistics, Production, Marketing and New Product Development," International Journal of Physical Distribution and Logistics Management, Vol. 26, No. 8, pp. 43-62 (1996).

19. Morash, E.A., Droge, C.L.M., and Vickery, S.K., "Strategic Logistics Capabilities for Competitive Advantage and Firm Success," Journal of Business Logistics, Vol. 17, No. 1, pp. 1-22 (1996).

20. Porter, M.E., The Competitive Advantages, Free Press, New York (1980).

21. Porter, M.E. and Miller, V.E., "How Information Gives you Competitive Advantages," Harvard Business Review, July-August, pp. 149-160 (1985).

22. Porter, M.E., The Competitive Advantage of Nations, Free Press, New York(1990).

23. Picard, J., "Physical Distribution Organization in Multinationals: the Position of Authority," International Journal of Physical Distribution and Material Management, Vol. 13, pp. 132-148 (1983).
24. Saaty, T.L., The Analytic Hierarchy Process, McGrawHill, New York (1980).

25. Saaty, T.L. and Vargas, L.G., The Logic of Priorities, Kluwer-Nijhoff, Boston, MA (1982).

26. Scannell, T., Vickery, S.K., and Droge, C.L., "Upstream Supply Chain Management and Competitive Performance in the Automotive Supply Industry," Journal of Business Logistics, Vol. 21, No. 1, pp. 23-48 (2000).

27. Shang, K.C., Building Sustained Competitive Advantage through Logistics Competency: an Empirical Study of the Manufacturing Industry in Taiwan, Logistics and Operations Management Section, Cardiff Business School, Cardiff University, London (2002).

28. Slack, N., "The Flexibility of Manufacturing Systems," International Journal of Operations \& Production Management, Vol. 7, No. 4, pp. 35-45 (1987).

29. Stalk, G., "Time: the Next Source of Competitive Advantage," Harvard Business Review, Vol. 66, No. 4, pp. 41-51 (1988).

30. Toffler, A., The Third Wave, Bantam Books, New York (1980).

31. Zadeh, L.A., "Fuzzy Sets," Information and Control, Vol. 8, pp. 338-353 (1965).

32. Zadeh, L.A., "The Concept of a Linguistic Variable and its Application to Approximate Reasoning," Information Science, Vol. 8, pp. 199-249. 